Revista Destaques Acadêmicos, Lajeado, v. 9, n. 2, 2017. ISSN 2176-3070

DOI: http://dx.doi.org/10.22410/issn.2176-3070.v9i2a2017.1402

www.univates.br/revistas

\title{
A COMPLEXA RELAÇÃO EGOÍSTICA ENTRE O HOMEM E O DINHEIRO: UMA ANÁLISE TEÓRICA A PARTIR DA FILOSOFIA E DA PSICOLOGIA
}

\author{
Tayson Ribeiro Teles ${ }^{1}$
}

Resumo: A maioria de nós humanos é egoísta e possui amor desproporcional pelo dinheiro como elemento integrante do cabedal de nossas características. Somos todos singulares, ímpares, únicos e irrepetíveis e, na medida do possível, amamos nosso semelhante, mas é notório nosso egoísmo. Pelo dinheiro elevamos nosso individualismo, massificamos nosso amor próprio, retornando à primitividade. É uma via de mão dupla: queremos dinheiro, pois somos egoístas e ao sermos egoístas queremos dinheiro somente para nós mesmos. Analisar, a partir de teoremas filosóficos e psicológicos, a complexa relação egoística entre o homem e o dinheiro é nosso objetivo neste artigo. À evidência, sem querer esgotar o tema, o trabalho, realizado por pesquisa bibliográfica qualitativa revisional, limita-se a mero plexo de reflexões filosóficas, as quais têm apenas o desejo de fomentar o debate sobre tema tão intenso. As conclusões indicam ser o dinheiro relevante ao homem, mas deve tal homem, em atenuação de seu egoísmo, pensar mais no seu próximo e agir em prol dele, a fim de que todos junto possamos ser/ estar felizes, realizados.

Palavras-chave: Homem e Dinheiro. Egoísmo. Filosofia. Psicologia. Reflexões.

\section{INTRODUÇÃO}

O dinheiro é um controvertido invento humano. Pode servir para o bem e para o mal. Pode ter origens boas ou ruins. Possui valor de uso e de troca. Sua fabricação e distribuição/circulação resvala em conceitos e pontos de tensão como mercadoria, produto, fetiche, vergonha, pobreza, autonomia, poder, alienação, liberdade, amor, ódio, dependência, dívida, morte, riqueza, mal-

1 Mestre em Linguagem e Identidade (Cultura e Sociedade) pela Universidade Federal do Acre - UFAC (2016) e Bacharel em Direito pela mesma instituição (2017). Especialista em Gestão de Políticas Públicas pela Universidade Federal de Ouro Preto - Minas Gerais (2016). Licenciado em Matemática, pelo Ceuclar/SP (2016). Graduado em Finanças, pela Faculdade UniSEB/ Estácio, de Ribeirão Preto - SP (2013). Técnico-administrativo Federal em Educação na UFAC. Membro do Grupo de Pesquisa "História e Cultura, Linguagem, Identidade e Memória" da $\mathrm{UFAC} / \mathrm{CNPq}$. 
estar, felicidade, angústia, honra, melancolia, inveja, sagrado, profano entre outros. Hodiernamente, nas atividades de nosso cotidiano, o uso do dinheiro, seja em papel, cartão de crédito/débito ou moedas virtuais outras, é banalizado - somos todos obrigados a usar o dinheiro, pelo sistema capitalista que nos engloba. Até um dito mendigo anticapitalista que pede ajudas em semáforos não prescinde deste bem humano - mesmo que peça comida, esta é comprada com dinheiro.

Levados pela força e poderio do cruel capital, apreendemos forçosamente, desde criança, em nossas mentes ideias que nos direcionam a acreditar na imprescindibilidade do dinheiro para nossas vidas. As ideologias do mercado global tentam nos convencer a todo o momento que não podemos viver sem o dinheiro. Desde nossas infâncias nos dizem que dinheiro não nasce em árvore, que devemos trabalhar duro - com muito esforço sacrificial, para termos dinheiro. Nossos pais nos educam centrados no dinheiro e sua importância: temos uma mesada; ganhamos um cofrinho para poupar; dãonos a responsabilidade de ir ao mercado comprar coisas, fazer contas e trazer o troco. Ao irmos à faculdade, com o fito de adquirir uma profissão, logo pensamos inicialmente nos salários das diversas formações laborais.

A humanidade transformou a natureza com o escopo de habitála e (re)significá-la de várias formas. Com a criação da moeda, os objetos foram convolados em mercadorias e adquiriram um valor externo a eles, um valor abstrato - uma aura, um valor mensurado pelo dinheiro, a partir de convenções humanas-sociais. Como praticamente é rara (a possibilidade de) uma propriedade coletiva do dinheiro, finda que o desejo (e as lutas) por este valor entrona $(\mathrm{m})$ no ser humano o egoísmo, o pensar só em si, o querer apenas o seu bem-estar individual.

Para termos objetos necessitamos de dinheiro, o qual, a partir disso, passa a exercer um papel enigmático em nós, que o vemos como a força geratriz de tudo. Enquanto trabalhadores, não conseguimos perlustrar nos objetos e serviços que produzimos nosso trabalho, nosso esforço, nosso suor. Somente conseguimos visualizar o valor fictício dos objetos e nos perguntamos se temos ou não condições de comprá-los. Nesse contexto, reificamo-nos, ou seja, na confusão mental de nosso dia a dia, ao lidarmos com tantos objetos e dinheiro, irrompemos em também nos apreendermos como objetos, como mercadorias compráveis e vendáveis.

Nessa loucura, buscamos sempre o lucro da vida, o que nos faz egoístas em demasiado. Das antigas moedas pesadas de ouro e prata, chegamos ao metal leve, ao papel, aos chips, às marcas. $\mathrm{O}$ valor agora advém da qualidade social dos objetos. Como o dinheiro serve para comprar coisas e nos é dito que ter muitas e grandes coisas, e coisas boas, é bom, bonito e agradável, finda por crescer na maioria de nós o que na psicologia se chama de Kratomania, ou seja, uma obsessão por poder, imponência e dominação - queremos casas 
enormes, carros potentes, bem como uma espécie de megalomania, uma mania de grandeza.

Nessa percepção, justifica-se como importante qualquer esforço teórico que tente debater o tema dinheiro e suas relações com a humanidade. Devemos, pois, esmerarmo-nos em via de questionamentos sobre a aparência dos objetos que vemos, desejamos e negociamos. Entendermos serem simulacros e sombras os objetos que nos apresentam em vitrines luxuosas. Questionar o glamour enigmático tecido pelo dinheiro e seus consectários. Duvidar do caráter real das relações humanas com o dinheiro, que, segundo o capital, satisfaz a incompletude humana. Buscar, num viés patologizante, a assunção do caráter alucinógeno, delirante e, em máximo grau, perverso e esquizofrênico das ligações entre o homem, o dinheiro e seu egoísmo.

Com espeque nesses pensamentos e indicações, por revisão bibliográfica qualitativa, objetivamos neste artigo tecer comentários teóricos obre a relação filosófica e psicológica existente entre o elemento social dinheiro e o ser humano e seu egoísmo. Dado o caráter filosófico do texto e a inarredável especulação da filosofia, o artigo carreia mais perguntas e reflexões ponderativas do que respostas e/ou soluções. Utilizamos como base teórica fomentadora da consecução do intento proposto a filosofia de Georg Simmel (1989) e algumas releituras deste autor realizadas por Marques (2011), bem como ideias de Santos (1999), Rand (1991), Schopenhauer (1995, 2001), Bacelar (2003), Flor (2009), Freud (1978) entre outros.

\section{O DINHEIRO E A PROPRIEDADE}

O dinheiro surgiu por vontade do homem. Nada surge do nada. Como diz Bakhtin (2012), todo ato humano é volitivo-emotivo, possui emoção e vontade/ação. O homem, então, por razões diversas, quis criar o dinheiro². Secundarizemos aqui, portanto, explicações para a origem do dinheiro, focando na relação entre este e o homem, relação tal em nosso tempo, nosso aqui e agora. Em nossa secularidade, "o dinheiro é pura flexibilidade, pura quantia. Assim despojado de conteúdo e qualidades, assim despojado de propriedades, o dinheiro não resiste, ajusta-se, líquido, a tudo" (MARQUES, 2011, p. 67).

Marques (2011), relendo Georg Simmel, diz que após o período em que os homens se desligaram da propriedade comum dos objetos - se um dia isso efetivamente houve, atualmente há uma ponte que nos religa à propriedade - porém, não comum: o dinheiro. "Dinheiro é pontífice (pontifex, fazedor de

2 "O dinheiro aparece em decorrência de uma vida econômica tornada complexa, quando o simples escambo já não basta, e ao longo do tempo acaba se impondo como um equivalente geral de todas as coisas que existem e são, ou serão, ou poderão ser, objeto de comércio. Desse modo, o dinheiro pretende ser a medida do valor que é [...] atribuído ao trabalho e aos seus resultados" (SANTOS, 1999, p. 8). 
pontes), é liberdade de quebrar todas as barreiras" (MARQUES, 2011, p. 68). O dinheiro é visto como a base de toda a propriedade, pois comporta-se como meio para quase todas as propriedades objetais existentes.

Estranhamente, o dinheiro é o maior perfectibilizador da propriedade, mas é ele também quem mais resiste à propriedade. $\mathrm{O}$ dinheiro recusa-se, filosoficamente, a ser acumulado nas mãos de muitos - fragmentariamente, e finda por ser amealhado por poucas mãos, as mãos dos poderosos, dos donos do poder, dos ricos, dos empresários, dos políticos, dos egoístas e individualistas que veem mas não se comovem com a fome de crianças e idosos em vários países do mundo.

Nada obstante a isso, para Simmel (1989), o dinheiro tem o desejo de anular a propriedade. Sim, é contraditório, mas aduz o autor que, por valer apenas enquanto dinheiro, este não quer deixar de ser dinheiro e, por isso, filosoficamente, ele prefere ficar nas mãos de quem não o converte em objetos, ou seja, de quem não o troca, não o vende, de quem o conserva (acumula) e no máximo multiplica (com investimentos).

É uma filosofia estranha e até romântica frente à ferocidade do capitalismo, mas é bem interessante. O pensamento de Simmel não é inócuo. É uma lógica verdadeira: o pobre não tem por que acumular dinheiro, tem necessidades mil, e ao ter algum dinheiro, o gasta. "O dinheiro só é real no momento de comprar algo, quando exerce a sua função de dinheiro" (MARQUES, 2011, p. 72). Portanto, para manter-se vivo, o dinheiro busca alocar-se em mãos que lhe deem fim adequado à sua criação. Ele só quer estar com quem pode gastá-lo, aumentá-lo, torná-lo real-concreto. Ele enoja quem o elimina, o usando apenas como ponte para necessidades básicas. Ao ver um rico, o dinheiro suspira de paixão.

Nessa perspectiva, em verdade, porém, o dinheiro não traz liberdade. Quem muito tem a ele fica preso; se o gasta, deixou de tê-lo - afinal, dinheiro é diferente de objetos. Além disso, nem todos os ricos são livres dos impulsos sensoriais, egoísticos e imediatos ${ }^{3}$. Marques (2011) evidencia que o homem ao longo de sua vida age possuindo as coisas. As coisas são os meios para que os homens alcancem seus fins. $O$ pesquisador tem razão, afinal usamos um carro para chegarmos ao trabalho, um caminhão para transportar alimentos de um local para outro etc. Os meios são recursos e, por isso, o dinheiro é tido como o mais importante recurso, pois pode nos possibilitar a posse de (quase) tudo, todos os recursos.

Assim, "a questão prática real é a produção de meios (recursos)" (MARQUES, 2011, p. 71). A cadeia teleológica do homem (pós) moderno é

3 Vale lembrar que, inclusive, o "sujeito, sob o domínio do desejo, não é livre em si, porque não se deixa determinar pela universalidade e racionalidade da vontade; e também não é livre em relação ao mundo exterior, pois o seu desejo é determinado pelos objetos" (SATIE, 2012, p. 71). 
inseparável do dinheiro. A técnica, os artefatos, os objetos, tudo (os meios), evolui e é necessário dinheiro para aperfeiçoá-los e comprá-los; surge, a partir daí, a atual supervalorização do dinheiro. O dinheiro é elevado à categoria de meio absoluto, meio dos meios. Desde criança nossos pais nos dizem: "não estrague, pois custa dinheiro!" (MARQUES, 2011). O dinheiro é o cara.

Refletir acerca do dinheiro não é fácil. Não podemos ser hipócritas, caro(a) leitor(a): todos gostamos de dinheiro. Cada um a seu modo, mas todos. Até um dito intelectual anti-materialista geralmente gosta de comprar livros. Devemos, nesse sentido, refletir sobre este "bem" humano no sentido de valor, de propriedade. Para Simmel (1989), o dinheiro não é ruim, o problema está em seu uso e interpretação ${ }^{4}$. Este filósofo disse que apenas somos donos daquilo que resiste a nós. Os objetos são objetos, diz ele, porque objetam (protestam contra) nossa vontade de possuí-los. Como assim, os objetos pensam? Bem, para Simmel nossa primeira propriedade é nosso corpo. Este corpo, aduz, não o dominamos integralmente.

Simmel assevera que podemos, por exemplo, pegar um de nossos braços e tentar dobrá-lo ao máximo, momento em que ele resistirá e não chegará ao seu limite sem se danificar, sem quebrar. Parece algo ridículo, a priori, mas tal pensamento é deveras filosófico. Simmel esclarece que o ser humano age do mesmo modo que os objetos: seu braço não dobra sem quebrar porque naturalmente o homem não pode englobar tanto ter (fazer).

Não há como o homem ser dono de tudo no mundo, bem como não há como todos os homens do mundo serem donos de uma mesma coisa. Se todos os homens deste planeta disputarem uma casa e ingressarem nela ao mesmo tempo, por exemplo, é óbvio que este imóvel resistirá a tal pretensão e permitirá que suas paredes se fissurem. É algo físico, mas filosófico também. Simmel usa tal metáfora para dizer que a partir de certa quantidade de objetos que o homem passa a possuir, como proprietário, este homem torna-se saturado. Logo, a receita ideal de vida é não se querer tudo ou muita coisa. Bem sabemos, no fundo do fundo de nossas vidas, que a felicidade está nas pequenas coisas, não é verdade?

Simmel esclarece que o homem que muito tem se torna escravo de seus objetos. Um homem com vários objetos diminui a capacidade de poder sobre cada um deles. Simmel engendra, assim, uma das mais brilhantes filosofias humanas modernas ao concluir que: "mais ter ou agir não é, definitivamente, poder mais, não é ser mais livre" (MARQUES, 2011, p. 67). De fato, isso é

4 Vários outros estudiosos não demonizam o dinheiro como fazem alguns marxistas esquizofrênicos. Weber, por exemplo, como lembra Amaral (2002, p. 3), "[...] aponta as consequências sociológicas gerais de seu uso como, [...], a possibilidade de troca de bens e a capacidade de se reservar valores para uso futuro". Não podemos, nessa direção, escrachar totalmente a existência do dinheiro, este é uma importante invenção humana. Devemos, com efeito, buscar alternativas para que todos possam tê-lo. 
verdade. Um homem que é dono de inúmeras coisas nunca terá tempo e capacidade para administrar tudo sozinho, seu poder será fragmentado, destroçado. Ele terá de contar com a ajuda de outras pessoas (geralmente, funcionários). Logo, o dinheiro nos proporciona a propriedade de objetos, de valores, de sensações, mas não é capaz de comprar tudo, nem tampouco de preencher nossos vazios torácicos existenciais. $\mathrm{O}$ dinheiro é relevante, mas apenas mais um valor humano. É desta forma que devemos todos enxergá-lo.

\section{O DINHEIRO E A (NEGATIVA) LIBERDADE NEGATIVA}

O dinheiro nos oferta a chamada liberdade negativa, ou seja, como prima Marques (2011), quanto mais dinheiro temos pouco precisamos fazer; positivamente, quase nada fazemos, temos tudo em nossas mãos. Quem possui muito dinheiro pouco pratica ações materiais, físicas, não trabalha pesado. Usa mais da linguagem (ordenando e pedindo) e da mente do que das mãos. $\mathrm{O}$ dinheiro pode (quase) tudo e finda por nos deixar confusos, não sabemos de seus limites. "Toda a potência do dinheiro lhe vem de não apontar a um fim, de deixar em aberto todas as possibilidades" (MARQUES, 2011, p. 74).

Atualmente, como diz Chomsky (2016), vivemos em um mundo onde os poderosos donos do mercado e do capital fabricam necessidades para as pessoas. O capital nos leva a todo o momento para coisas superficiais; encantam-nos com "baladas" (festas) cheias de luzes, com filmes em telas imensas, com sapatos que brilham, roupas que esticam, chocolates viciantes. Estão nos atomizando, instigando-nos a elevar cada dia mais nossa ganância. Afastando-nos de esforços que possam nos levar a pensar por nós mesmos, a questionarmos as autoridades deles. Eles, os que fabricam o dinheiro e que nos tomam o pouquinho que conseguimos ter com muito trabalho.

Chomsky (2016) lembra que Edward Bernays chamou isso de "engenharia do consentimento". Os engenheiros desse sistema cruel que nos encobre são pessoas que se acham deveras superiores, que creem ter a missão de dominarem o mundo. Acreditam que a maioria das pessoas são ignorantes e estúpidas, praticamente incapazes de gerenciar suas próprias vidas, precisando deles, os "feras", os "caras", os "expertos", os que controlam as técnicas, os donos dos recursos.

Veem-nos (os donos do poder) como espectadores no sentido da expressão abrasileirada: "expectantes de dores"; liberadores de dores, sofredores, observadores da desgraça (a nossa). Vivemos dominados pela mente. Como clarifica ainda Chomsky (2016), com o tempo, o Estado violento 
foi e está perdendo o "respeito", está sendo constrangido 5 pelo discurso dos direitos humanos, da democracia, querem, então, nos dominar pela mente, pela "opinião pública produzida", delimitar as informações a que podemos ter acesso. Precisamos buscar alternativas já, posto que a luta é a longo prazo.

Vivemos algo além do que Foucault chamou de Bipoder/Bipolítica. Estamos no que Achille Mbembe (2014) chama de Necropolítica ou Necropower, ou seja, um poder da morte, poder dos mortos. Os poderosos forjam tecnologias de destruição, as quais são táteis, sensoriais, anatômicas. Tais armas, como sustentáculos do capitalismo selvagem, provocam a existência de sociedades que vivem praticamente mortas com relação às suas condições de vida, como ocorre em algumas partes da África e do Oriente médio, mormente a Palestina.

Vige em nosso tempo um consumismo exacerbado. Pensamos que podemos comprar pessoas, valores. Nas relações diárias:

O outro é tratado como um objeto de consumo e julgado pelo volume de prazer que [...] oferece. É uma forma de relacionamento em que se entra pelo que pode ganhar e se continua [...] enquanto ambas as partes imaginem que estão proporcionando [...] satisfações suficientes (BAUMAM, 2004, p. 111).

O homem pós-moderno é muito confuso. Durante a semana inteira é um animal feroz à busca constante por dinheiro. Aos domingos à noite vai à igreja deixar parte do que ganhou para o pastor do qual é uma "ovelha" indefesa. Deseja relacionamentos duradouros, mas quando se enraíza a alguém se ressente das outras possibilidades que perdeu - ou que está perdendo, vive frustrado, triste, melancólico. Prega e valoriza a fidelidade como ideal, mas não é fiel. Ora, é preciso mudar, ser sincero, fazer escolhas éticas ${ }^{6}$.

Vivemos em um tempo "estranho", uma época sem sentido/senso histórico. Há um vazio em nossas vidas. Parece que estamos vagando, não conseguimos determinar nosso tempo. Sabemos o que houve em praticamente todos os séculos passados, as correntes que existiram, as tecnologias etc. Contudo, não sabemos nada sobre o futuro. Nunca houve isso, pois sempre havia algo a descobrir e hoje parece que temos tudo. Vemos imagens da

5 Não há mais violência explícita, mas "hoje a tirania, o autoritarismo, o totalitarismo político, econômico e educacional e mais uma série de tantos outros centralismos são exercidos na medida exata" (SACADURA ROCHA, 2011, p. 101), de forma tênue; vigiam-nos mais sutilmente, por satélites, programas, câmeras.

6 Não discursamos aqui em tom professoral, pois também nos colocamos neste lugar, cometemos estes mesmos erros e, nesse sentido, buscamos aqui refletir. 
Terra em tempo real a flutuar no nada - o Universo, o tempo a passar e nos desesperamos ${ }^{7}$.

“[...] Uma vez que a sociedade não tem futuro, faz sentido vivermos somente para o momento, fixarmos nossos olhos em nossos próprios desempenhos particulares, tornamo-nos peritos em nossa própria decadência, cultivamos uma 'autoatenção transcendental'" (STENGEL; VIEIRA, 2010, p. 3). Esse é o cruel ideal que nos tem sido imposto! Só pensamos em nós mesmos. Quando pensamos em outrem é planejando no que nosso Outro pode nos ajudar a nos desenvolvermos - o que ele pode nos proporcionar?

Nesse meandro, tem sido perigosa a tênue relação entre o dinheiro e a família. "A conjugalidade é percebida como algo que pode ameaçar as individualidades" (STENGEL; VIEIRA, 2010, p. 9). Os casais e demais companheiros(as) se "amam", mas cada um tem sua conta bancária, com sua poupança, seu carro, suas senhas do celular etc. Sempre que liberdades são cerceadas ou adquire-se uma melancolia por estarem-se perdendo outras oportunidades no viver (tidas como melhor), as relações são quebradas. O amor e companheirismo (sub)existem, mas sobrevivem à espreita de desejos individuais diversos que ladeiam as pessoas que erigem relações de um modo geral. Todo mundo tem um plano " $b$ " para tudo - para relações amorosas, laborais etc.

Em nossas vidas, o dinheiro:

[...] e suas técnicas de informação [...] nos levam à ilusão da velocidade, como matriz de tudo, como necessidade indispensável e que certamente criam uma fluidez potencial transformada nessa fluidez efetiva a serviço de capitais globalizados, de tal modo que o dinheiro aparece como fluido dos fluidos, o elemento que imprime velocidade aos outros elementos da história. [...] o comando se dá a partir do dinheiro global. Esse dinheiro fluido, que é também invisível, um dinheiro tornado praticamente abstrato, um dinheiro global e um dinheiro despótico [...] um dinheiro sustentado por um sistema ideológico. Esse dinheiro global é o equivalente geral dele próprio. E por isso ele funciona de forma autônoma e a partir de normas. [...]. Nossa era se caracteriza sobretudo por essas ditaduras: a ditadura da informação e a ditadura do dinheiro, e a ditadura do dinheiro não seria possível sem a ditadura da informação. $O$ dinheiro em estado puro nutre-se da informação impura, tornada possível quando imaginávamos que ela seria cristalina (SANTOS, 1999, p. 10-11). (Grifos nossos)

7 Em épocas passadas não se tinha acesso a tais imagens, não havia tantas tecnologias. A visão do homem era mais limitada, terrena, o mundo lhe parecia grande, inacabável, havia muita coisa a viver, a conhecer. 
Estamos no período em que o dinheiro é (como um) Deus. Daqui a algum tempo predominarão os chips, mas hoje quem manda é o dinheiro. $\mathrm{O}$ dinheiro de hoje é "um discurso único perfeitamente elaborado, e que se torna acreditável a partir do bombardeio das mídias, mas também a partir da chancela da Universidade" (SANTOS, 1999, p. 11). Sim, hoje nossos adolescentes são instigados a estudar para ingressar no mercado profissional e fazer o quê? Ganhar dinheiro!

Inarredavelmente, nos dias presentes nossas vidas são subsumidas aos ditames do dinheiro e seu poder:

Esse poder que é cego, porque não olha ao redor. Esse poder que se preocupa com objetivos precisos, individualistas, egoísticos, pragmáticos é um poder cego, já que não olha ao redor. Mas escolhe lugares aqui e ali, hoje e amanhã, em função das respostas que imaginam poder ter, e desertam esses lugares quando descobrem que já não podem oferecer [...] respostas (SANTOS, 1999, p. 11).

E quem será que governa este poder? O Estado? As instituições jurídicas? Na verdade não. Quem governa o dinheiro são os empresários, os banqueiros, os industriais, os quais, por via de consequência, são os donos indiretos do Estado, da política - as delações da Odebrecht e da JBS não nos deixam mentir. A administração do dinheiro mundial "[...] não pode ser confiada aos Estados, porque estes podem decidir atender aos reclames das populações" (SANTOS, 1999, p. 11), então, surgem os Bancos, o Fundo Monetário Internacional, as empresas e as Universidades produtoras e reprodutoras de ideias globalizantes que nos fazem crer serem eles os mais capazes de gerir nossas riquezas e ser o dinheiro o fim de tudo ${ }^{8}$.

\section{O DINHEIRO COMO STATUS SOCIAL}

O dinheiro também é status, "[...] dá-nos possibilidade e poder, dá-nos liberdade de irmos e chegarmos a tudo ao custo de não atermos ao objeto, ao outro, a nada que não o dinheiro" (MARQUES, 2011, p. 91). "O pobre, por necessidade, por sentir na pele essa resistência de que o dinheiro livra, é todo ele inversão da liberdade" (MARQUES, 2011, p. 92). Com dinheiro compramos roupas das mais conceituadas marcas, nos vestimos e somos bem atendidos em

8 Vale lembrar, em síntese, que quanto a este Estado moderno/pós-moderno e global, “a adesão à racionalidade objetiva do Estado moderno pode efetuar-se de dois modos: ou nos submetemos à força coercitiva de suas instituições e leis, ou aceitamos conviver com ela, segundo o conhecimento e a internalização de sua dinâmica já existente. Ou seja, em nosso tempo não produzimos o universal tomando por base nossas ações singulares; apenas reproduzimos a universalidade vigente por meio do conhecimento de suas leis e, de certa forma, podemos afirmar que, sob tal ordem, toda ação criativa que a transgrida será castigada" (SATIE, 2012, p. $74)$. 
lojas, em restaurantes. Com roupas simples, somos mal vistos. Caçoam de nós. Quanta hipocrisia!

Será mesmo que ser pobre tem a ver com ter dinheiro? Bem:

Posso ser pobre sem o ser: porque nesta classe social não consigo suprir as necessidades de minha classe; porque minhas necessidades ultrapassam as de minha classe que consigo suprir; porque tão rico as minhas necessidades em nada coincidem com as de minha classe (MARQUES, 2011, p. 93).

Assim, mesmo entre os ricos há pobres. O "rico" é apenas um gênero. Os ricos não são todos iguais. Alguém sempre terá mais que você, a não ser que você seja o homem mais rico do mundo - o qual também não tem tudo nem

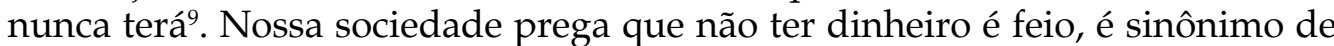
fracasso, de derrota. É apregoado que "se esconda e negue a pobreza: é de aceitar assistência que a pobreza se faz pobre, à margem, desclassificada" (MARQUES, 2011, p. 93). Surgem, nesse sentido, os chamados "pobres orgulhosos", aqueles que, à beira do vale da morte, da fome, relutam e negam precisar do Outro, negam sucumbir à aceitabilidade da existência de revoltantes desigualdades.

Grita o contemporâneo mundo que se você não tem dinheiro "todos os seus restantes atributos destacados nada mais que pobres são" (MARQUES, 2011, p. 93). Os poderosos transformaram o adjetivo pobre em substantivo: não é pobre, é "o pobre", como se não fosse possível deixar de sê-lo (felizmente é, mas infelizmente pela ridícula meritocracia). A pobreza é representada em feixes imanentes a relações de poder. Se você não tem dinheiro ou tem pouco, você está condenado a não ter poder algum.

Nessa direção, precisamos lembrar que:

As representações do mundo social [...] embora aspirem à universalidade de um diagnóstico fundado na razão, são sempre determinadas pelos interesses de grupo que as forjam. Daí, para cada caso, o necessário relacionamento dos discursos proferidos com a posição de quem os utiliza. [...] Por isso, [...] investigação sobre representações supõe-nas como estando sempre colocadas num campo de concorrências e de competições cujos desafios se enunciam em termos de poder e de dominação (CHARTIER, 1990, p. 17).

9 Como disse certa vez o poeta e Ex-presidente do Supremo Tribunal Federal, Ayres Brito, "nem Deus pode tudo". Isto é, Deus criou o poder, ele é o poder, ele é Deus, logo, ele pode tudo exceto "parar de poder". Não há como Deus exclamar: "não quero mais ter poder". Ora, ele é Deus. Assim, ele não pode tudo, pois não pode parar de poder. 
É premente que percebamos o uso errado que a humanidade tem feito do dinheiro. Era para este bem servir de facilitador das relações humanas, mas tem servido como chefe da subserviência e como diferenciador dos "tipos" de ser humano. Bourdieu (2001) assevera que é possível saber a que tipo de classe social pertence um ser humano por meio da observação de algumas características, hábitos etc., notadamente os relacionados aos cuidados com o corpo, às vestes, aos acessórios estéticos. E todos estes aparatos são comprados com dinheiro.

De fato ao olharmos para uma pessoa, com raras exceções, conseguimos saber ela tem muito, pouco ou média quantidade de dinheiro. Os corpos de todos nós estão marcados indelevelmente. Se temos dinheiro, quase todos nós, queremos mostrar que temos, a fim de sermos valorizados como quem tem. "Não é apenas a busca pela saúde e beleza ${ }^{10}$ que faz com que pessoas gastem fortunas para ter o corpo ideal, mas também pelo status que ele pode proporcionar, uma vez que ele é um meio de representação social" (FLOR, 2009, p. 271).

De um modo geral, "o cuidado com a boa forma não é motivado apenas pela saúde, mas também pela boa aparência física, o prestígio social de ostentar um corpo magro, persistência, determinação, e por se enquadrar no estereótipo ditado pela mídia e aceito pela sociedade" (FLOR, 2009, p. 272). Nesse prisma, em nosso momentum:

A mídia repete incessantemente que ser belo é ser magro e, implicitamente, ser belo, magro, é ser de boa condição social, pois o indivíduo pode pagar uma academia, fazer lipoaspiração, dieta e comprar cosméticos caros. Dessa forma, o padrão de beleza construído pela mídia pode ser resumido em magreza e riqueza (FLOR, 2009, p. 273).

Como vocifera Barth (2010), atualmente as pessoas têm se importado muito com sua aparência física, com seu vestuário e, a partir disso, estão querendo ser raras, exclusivas, restritas. Na busca por uma exagerada diferenciação do resto da humanidade, busca-se o privilégio, as simbologias de luxo, nobreza, riqueza, prestígio, estilo.

Nesse foco:

Um ponto interessante é a questão paradoxal que envolve o Brasil, um país com imensos problemas sociais - onde expressiva parcela da população vive em estágio de extrema pobreza -, mas que, também, apresenta grandes tendências ao consumo de produtos de luxo, as

10 "Não desejamos a beleza; desejamos, sim, aquilo que nos falta, com o intuito de preenchermos um vazio determinado" (SATIE, 2009, p. 31). 
quais começam a chamar a atenção tanto dos estudiosos quanto do público em geral. [...] uma das peculiaridades do mercado brasileiro é que, diferentemente de outros países (onde o turista internacional movimenta as vendas), os produtos de luxo no Brasil são quase totalmente voltados para a clientela local. As marcas que investem no país há mais tempo já se adaptaram às características do mercado, como comprar a prazo, parcelar compras no cartão de crédito. Isso facilita o acesso de classes menos abastadas aos bens de prestígio (BARTH, 2010, p. 7). (Grifos nossos)

Cremos, todavia, nesse contexto, que o homem precisa entender, ou lembrar, que a mídia lhe oferece produtos o tempo inteiro - produtos tais que oferece pregando, por linguagens simbólicas, serem produtos elevadores do status social, do respeito, do respaldo perante a sociedade -, mas tal mídia, em verdade, objetiva controlar-nos. Domar-nos como animais. A mídia, e a brasileira é especialista nisso, tem como objetivo primordial determinar o assunto de nossas conversas nas ruas ${ }^{11}$, nas escolas, nos bares, nas igrejas - quando se conversa nas igrejas, posto que geralmente se fica em filas para debitar dízimo em cartão de crédito.

Acreditamos que o dinheiro deveria ser mais visto como um bem do que como um construtor e mantenedor de status social. Deveria o dinheiro ser o bem humano utilizado como meio para fazer o bem, distribuir riquezas aos menos favorecidos. Todos, em atitude egoística, adoramos ao dinheiro. Até o Estado, representado notadamente pelo Direito, pelas regras e pelos agentes públicos, não foge à adoração ao dinheiro. As profissões jurídicas e as carreiras de gestão da Administração Pública, de um modo geral, lidam com muito dinheiro, possuem salários elevados, gerenciam enormes patrimônios, regulam fortunas.

Os honorários advocatícios, por exemplo, são elevadíssimos, existem mínimos, não pode o advogado cobrar pouco, abaixo do tabelado, pois estará "aviltando" a profissão, é o que dizem os membros e gerentes dos Conselhos da OAB. Alguns causídicos auferem milhões em uma causa. "O Direito é uma instância nitidamente retórica, cuja verdade é apenas um luxo, mas nunca parte essencial do seu conteúdo, de modo que, para o advogado, ganhar causas é muito mais relevante do que provar hipóteses" (BASTOS, 2012, p. 173).

Entrementes, há algumas táticas do Direito que ajudam os detentores de muito dinheiro a conseguirem administrar suas fortunas como um bem agregado, estável e administrável. Os direitos civil, comercial e empresarial surgem com regras, contratos, formas de compra e venda, os quais padronizam

11 O comportamento da mídia, no Brasil, ajuda somente a maximizar interesses das elites na medida em que, conforme Abreu (2016), as programações direcionadas às minorias são exíguas, o que faz delas classes desprovidas de possibilidade de intervir no jogo político, ficando excluídas perenemente da sociedade (o Estado de exceção de que fala Agamben). 
as relações entre o dono e as outras pessoas envolvidas em seus negócios. Toda essa confluência de coisas serve, ainda, para administrar os eventuais conflitos existentes entre sócios, clientes e empresários, patrões e empregados etc. Como disse Weber, relido por outro: "[...] o Direito é central numa sociedade capitalista. Ele cumpre um papel na economia por meio do 'contrato', que é garantido pela ameaça de coerção legal” (AMARAL, 2002, p. 3).

Além disso, também existem conflitos entre pessoas comuns (pessoas físicas) por dinheiro. Estão os juizados abarrotados de feitos/processos a não nos deixar mentir. Simmel (1989) nos conta que o que tem elevado os conflitos urbanos por dinheiro é exatamente a urbanização. Em uma espécie de psicologia metropolitana, ele nos diz que, por fazer parte de um plexo de vários círculos sociais, o homem urbano sente-se livre, acha que por poder escolher produtos tem poder de escolha e finda por às vezes ingressar em cadeia incontrolável de dívidas com outros, os quais "por direito" acionam a justiça para cobrar. Isso é problemático, porquanto a possibilidade de escolha de produtos não significa liberdade. Escolha é diferente de decisão.

\section{PONDERAÇÕES TEÓRICO-PSICOLÓGICAS SOBRE O EGOÍSMO HUMANO E O AMOR DESMESURADO PELO DINHEIRO}

O homem ama sem medida o dinheiro principalmente porque é egoísta. Somente pensa em si, em sua família, seus bens, sua saúde. "O egoísmo é colossal, ele comanda o mundo. Se fosse dado, pois, a um indivíduo escolher entre a própria aniquilação e a do mundo, nem preciso dizer para onde a maioria se inclinaria" (SCHOPENHAUER, 2001, p. 121). Mas, o que é ser egoísta? Pensamos que conceituar o egoísmo pode ser bem atendido se nos voltarmos para a psicologia, enquanto a Ciência que se debruça mais acuradamente para estudos sobre a mente e o comportamento humanos.

Apenas para rememorarmos, "de uma maneira geral, costuma-se definir a psicologia como Ciência da alma. Com efeito, psychê, geralmente traduzida por alma, designa aquilo que os gregos entendiam por princípio de vida" (BACELAR, 2003, p. 30). Diz Mira y López (2005) que a psicologia visa a estudar, analisar e classificar o modus operandi do ser humano, em uma perspectiva além dos aspectos físicos e biológicos, a fim de construir uma rede associativa de significados simbólicos mentalmente construídos pelo homem no mundo que o cerca. Cabe à psicologia, por exemplo, ao invés de dizer que um crime cometido por uma pessoa com deficiência mental foi um crime "sem motivos", dizer que foi um crime motivado por causas psicológicas e explicálas.

Falemos, então, um pouco sobre o egoísmo do ponto de vista psicológico. Cassirer (1992), rememorando John Locke, acredita que "o mal-estar e a inquietação são o verdadeiro motor e o impulso decisivo de todo o nosso querer" (CASSIRER, 1992, p. 147), ou seja, o ser humano em quase tudo o que 
faz é movido pelo desejo de se livrar do mal-estar que tem ou age planejando não adquirir tal mal-estar ${ }^{12}$.

Além do mal-estar, a inquietação natural do ser humano, que a todo o momento não consegue quedar-se sem nada fazer - talvez por certa inescapabilidade do agir provocada pelos próprios aspectos biológicos dele, por exemplo, os fatos de seus órgãos nunca pararem de funcionar, seus olhos piscarem sem sua vontade etc. - também é um grande impulsionador da ação humana (BACELAR, 2003).

Ocorre que, nessa perspectiva de ser movido por receio do mal-estar e pela inquietação, o homem sempre se move em um grupo e, nesse rumo, precisamos ter em mente que:

O principal elo entre indivíduo e grupo é o interesse, que significa literalmente "estar entre, no meio"13 (FERREIRA, 1986, p. 957), o que evidencia o caráter relacional do termo, que diz respeito à capacidade das coisas de satisfazer as necessidades humanas. $\mathrm{O}$ vínculo de uma pessoa com determinado grupo será tanto mais forte quanto mais importante for a necessidade que esse último é capaz de atender (ABREU, 2016, n.p.) (Grifos nossos).

Nesse alamiré, grosso modo, não conseguimos entender o agir/ato do homem, posto que ele é o que é. O que conseguimos é entender os motivos de tal agir. Tais motivos "são fundamentos psicológicos que justificam uma ação; são impulsões psíquicas. Em suma, o motivo é a razão de movimento, uma razão do agir humano e animal" (BACELAR, 2003, p. 31). Neste aspecto, apesar de filósofo, um grande colaborador dos conhecimentos psicológicos humanos foi Schopenhauer, que disse:

\begin{abstract}
A motivação principal e fundamental [do agir] tanto no homem como no animal, é o egoísmo, quer dizer, o ímpeto para a existência e o bem estar [...]. Este egoísmo é ligado o mais estreitamente possível, tanto no homem quanto no animal, com o âmago e o ser mais íntimo deles e lhes é propriamente idêntico (SCHOPENHAUER, 1995, p. 114) (Grifos nossos).
\end{abstract}

Mas, como assim, Schopenhauer nos iguala aos animais no ato de agir egoisticamente? Ora, não nos achamos efetivamente "melhores" que os animais? Bem, para Schopenhauer o homem e o animal basicamente têm as

12 Tal mal-estar pode ser um conjunto de situações ruins, problemas a resolver, cansaço etc., mas essencialmente é aquele "vazio" impregnado no tórax da maioria dos homens, que alguns tentam preencher com álcool, outros com drogas, outros com livros, outros com sexo, outros com Deus(es).

13 Interesse $=$ entre + esse. 
mesmas vontades, quais sejam: dar-se bem! E para tal apenas pensam em si. Como assim, os animais pensam? Esta questão é complexa.

Por ora, tenhamos na mente que, conforme Schopenhauer, a diferença entre o homem e o animal não está na distinção entre vontade e intelecto, mas na separação entre o intelecto e a razão. Exclusivamente humana, a razão é "a faculdade de representações gerais e não-intuitivas, chamadas conceitos, que são designados e fixados por palavras" (SCHOPENHAUER, 1995, p. 54). Assim, os animais pensam sim, possuem vontade e intelecto. É algo lógico, para mexer a cabeça um pássaro, por exemplo, precisa querer. O que tal animal não possui é a razão, ou seja, a interpretação da lógica racional das coisas/conceitos (as previsões/planejamentos + os atos + as consequências).

Para Schopenhauer, o homem por possuir capacidade de abstração, o planejamento das ações (antecipar as consequências), e autodomínio, é o único ser vivo capaz de seguir uma moral (entendamos aqui como lei/costume/ Direito). Ou seja, por prever consequências, por exemplo as penas dos crimes, é que o homem consegue seguir/obedecer a leis. Os animais, a contrario sensu, não têm o dom da previsão. ${ }^{14}$

Luz (2014), rememorando Hobbes, aduz que o homem é egoísta e não consegue viver igual a alguns tipos de animais, como as formigas que vivem em plena comunidade, porquanto apenas ele (o homem) possui disputas por honra e precedência. Apenas o homem possui ódio, emulação e inveja. Apenas o homem consegue injuriar o outro. Os animais não têm noção do que seja causar dano a um de seus semelhantes. Além disso, diz o autor que, diferentemente dos animais, numa multidão de homens sempre haverá aqueles que creem ser mais sábios que os outros, os quais tenderão a querer dominar, se sobressair, governar.

Outrossim, Schopenhauer (1995), então, diz que deve o homem, para moralizar todas as suas ações, ou seja, engendrá-las de modo ético, justo etc., deixar de ser egoísta, afinal, "as ações egoístas resultam sempre no mal" (BACELAR, 2003, p. 33). Quer dizer, em tese, pois existem ações filantrópicas que podem ser resultado de ações egoísticas dissimuladas, de políticos mal intencionados em campanha, por exemplo.

Mas, em síntese, "a ausência de motivação egoísta [nas ações humanas] é, portanto, o critério de uma ação dotada de moral" (SCHOPENHAUER, 1995, p. 124). Sim, é uma visão romântica e pré-maquiavélica que vê a vida como ela deveria ser e não como ela é na rua, no chão de barro, mas é uma interessante

14 No fundo do fundo, essencialmente o homem e o animal pouco diferem, posto que "há no homem um traço de bestialidade que é irredutível e que acaba por tornar toda a existência refém do caos e do vazio" (DELRUELLE, 2004, p. 34). Soltemos um homem numa floresta sem alimento e ele se revela naturalmente! 
visão. Tentemos nos livrar de nossos egoísmos, de nosso amor fulcral pelo dinheiro, ajudemos nosso Outro e vejamos se não seremos mais felizes?

De revés, o idealismo de Schopenhauer ao pensar ser possível que o ser humano aja desprovido de egoísmo, sendo, por isso, um ser moral ou comportando-se moralmente é interessante, mas merece críticas. Cremos, humildemente, não ser possível generalizar e dizer que se desprendendo do egoísmo no "seguir das regras/leis" o homem convola-se automaticamente em um ser moral, pois nem sempre a moral será moral em si mesma. Dizemos: não adiante ser o homem bom e caridoso se as leis a que deve seguir são ruins, maliciosas, instam-no a ser individualista - como as leis atuais provindas das ideologias burguesas pós-revoluções liberais.

Outro problema é que é praticamente impossível que todos sejam éticos, morais, caridosos, adjuvadores do próximo (e do distante também), posto que algumas pessoas são por natureza más. Algumas crianças agem como "monstrinhos", beliscam os amiguinhos, agem de forma má. É a nossa opinião! Não queremos aqui polemizar a já tão polemizada díade maniqueísta entre os pensamentos de Hobbes e Rousseau ${ }^{15}$, mas cremos sim que alguns homens por natureza são maus, sendo impraticável concebermos uma compaixão absoluta.

Afinal:

[...] a compaixão, enquanto sentimento natural, somente existe mais ou menos. Existem na verdade seres humanos que, diante de qualquer sofrimento, reagem espontaneamente com compaixão, mas a maioria faz isso apenas parcialmente, e em alguns existe, mais forte que a compaixão, o seu sentimento contrário, a satisfação pelo mal alheio e o prazer na crueldade (desumanidade) (TUGENDHAT, 1996, p. 196) (Grifos nossos).

Ademais, o egoísmo humano, a partir da psicologia, também exerce caráter terrorífico junto ao amor ao dinheiro. A criança quer objetos vários e o adulto cresce querendo progredir, enriquecer, transformar-se no "cara", aquele que tem "a coisa" - o dinheiro. Freud (1908/1978) acreditava que há relações entre os órgãos sexuais e os filhos: o homem protege o pênis como a um filho, pois o pênis tem o poder de lhe dar mais filhos e a mulher protege a vagina como a uma filha, pelo mesmo motivo. Nesse contexto, achava também haver relações entre as fezes e o dinheiro.

15 Vale lembrar que para Hobbes o homem é originária e essencialmente egoísta e seu egoísmo é diminuído pela educação e pela interação que erige com seus congêneres, sob a coerção imposta pela lei/Estado, que limita a liberdade de cada um para que possa ser a lei válida para todos ("o homem é o lobo do próprio homem"), bem como para Rousseau o ser humano nasce livre e essencialmente altruísta, sendo o acorrentamento da sociedade que dele faz um homem mesquinho, ganancioso e egoísta ("o homem nasce bom e a sociedade o transforma"). 
Para Freud (1908/1978), em seu "Caráter e erotismo anal", fezes remete a "fazer": as fezes são um fazer humano, um trabalho. As fezes dão trabalho para ser feitas, seu processo de feitura/liberação ocasiona prazer, logo que feitas se perdem e são consideradas um objeto maldito, um tabu - elas não devem ser tocadas. Igualmente, o dinheiro é feito pelo homem, é obtido com muito trabalho, sua circulação (o gastar) é prazeroso e ele logo se perde, é gasto facilmente. Freud entendia que, do mesmo modo que as fezes, que são o produto final da energia máxima (nutrientes) de que precisa o ser humano algumas fezes animais são tão fortes que servem de adubo, o dinheiro possui um valor inestimado ao mesmo tempo em que é enojado, é tido como sujo.

Freud (1908/1978) ressaltou que o ser humano possui relação contraditória com o dinheiro. Conforme o autor, o homem repugna as fezes, porquanto tem angústia de que o que dele sai seja reprovado pela sociedade. Ao temer que o saído de seu interior não seja aprovado pelo outro, o homem retém suas fezes dentro de si sempre que pode e consegue - busca banheiros para fazer suas necessidades.

Freud aduz que o mesmo é feito com o dinheiro: o homem esconde quando e quanto ganha, não fala sobre; ao fazer uma transação comercial, negocia e deixa o pagamento para o final, prefere não ficar tocando no dinheiro, basta tocar o mínimo, repassá-lo rapidamente. O homem não anda mostrando o dinheiro. Os que circulam com dinheiro em mãos à vista são tidos como suspeitos de algo - ladrões ou "desorganizados", sem modos etc. É como se o dinheiro-objeto pudesse estragar as cenas do teatro social. São interesses reflexões do pai da Psicanálise.

\section{A (IM)POSSIBILIDADE DO FIM DO EGOÍSMO HUMANO: NÃO HAVERIA MESMO SAÍDA? QUE TAL PENSAR NO OUTRO?}

Então, nas perspectivas psicológica e filosófica, é o egoísmo ineliminável? Sim, parece que sim. Infelizmente - para nós - sim. Seria bem interessante que o homem de um modo geral não fosse egoísta, não tivesse "vontade de ser egoísta", mas, quanto a essa vontade, disse Schopenhauer (2001) que a negação da vontade de agir egoisticamente não consiste apenas em ter horror aos males da vida, mas também em detestar os gozos e "prazeres" de tais males, ou seja, não basta querer fazer o bem, é preciso "odiar fazer o mal", o que muitas pessoas não conseguem, por vários aspectos, realizarem.

Porém, como fica o preceito Socrático de que "ninguém pratica o mal voluntariamente"? Bem, Delruelle (2004), comentando Sócrates, aduz que realmente o homem naturalmente procura o bem, que a vontade do homem tende naturalmente para a felicidade. Entretanto, os homens vivem mesmo a maior parcela do tempo de suas vidas ladeados de infelicidade, de frustrações, de vários "se eu tivesse conseguido", de alguns "se eu tivesse feito assim assado", vivem em vales de mentiras. Qual a razão disso? Por que os homens 
praticam o mal se tendem para o bem? "Sugere Sócrates, [...] é porque ignoram o bem, porque estão enganados quanto à natureza do bem, confundindo-o, por exemplo, com o poder, o dinheiro ou as honrarias" (DELRUELLE, 2004, p. 44).

O homem é complexo. Mata uma formiga ou uma barata que mal nenhum lhe faz, apenas porque há um discurso - confirmado pela Ciência estatal -, de que tais bichos são anti-higiênicos. O homem estaciona na vaga do deficiente físico e alega ter sido só uma "paradinha" para comprar algo. $\mathrm{O}$ homem entra no ônibus, senta na vaga do idoso, ingressa um ancião no coletivo e ele finge estar dormindo.

O homem é dono de uma barraca na praia e quando o sol está bem forte ele eleva o valor do aluguel de cadeiras, o preço da água de coco, posto que vai ter mais clientes. O homem só pensa no seu bem, nos seus ganhos e tem a "cara de pau" de reclamar dos políticos, dos empresários corruptos. Ora, os políticos (alguns) roubam bilhões e para eles foi apenas uma "roubadinha", fraudam licitações e para eles foi apenas uma "fraudadinha". É deveras complexo viver, mormente no Brasil.

Os brasileiros reclamam dos políticos, das leis (que em sua maioria são erradas mesmo, posto que feitas pelas elites em benefício próprio), mas não dão uma segunda chance a ex-presidiários que de fato queiram trabalhar, mudar de vida, ofertando-lhes, por exemplo, empregos ou não demonstrando preconceitos diversos. Recentemente reclamamos dos pronunciamentos de nossos Deputados Federais durante a votação do pedido de impeachment da presidente Dilma Rousseff. Criticamos que os parlamentares apenas falaram em nome de suas famílias, de seus eleitores, suas cidades, seus tios, suas avós etc. Ora, eles são nossos espelhos, são egoístas porque somos todos egoístas. Não poderíamos esperar outras falas, com raras exceções - salvo um engano apenas o Deputado "Tiririca" alegou votar "pelo Brasil", o que não temos como saber ser verdade ${ }^{16}$.

Ademais, embora pareça ser impossível obliterarmos o egoísmo e o consequente elevado amor que temos pelo dinheiro, seria interessante que

16 Vale lembrarmos que, malgrado esteja se esforçando, se presentificando até mais que os outros, apresentando projetos, o Deputado Tiririca já externou em várias entrevistas que ele foi procurado pelo presidente de seu partido, o Deputado Valdemar Costa Neto, que alegou já ter feito pesquisas que indicavam que Tiririca poderia ser eleito, o qual lhe fez a proposta para que ele fosse candidato, a fim de eleger outros membros do Partido (PR), pelo coeficiente, bem como amealhar mais recursos à legenda. Tiririca, disse claramente, por várias vezes, que aceitou pensando em sua carreira, em obter mais visibilidade, bem como pelo fato de que ele não gastou um real sequer em sua campanha - o partido pagou tudo. Inclusive, depois de eleito disse que estava perdendo dinheiro, pois cada Show seu é mais de 100 mil reais e, por conta de ter de ficar em Brasília de terça à quinta-feira, ganhando apenas 33 mil reais por mês como parlamentar, estava perdendo de fazer Shows. Ao fim do mandato disse desistir da política, mas voltou atrás. Dizemos tais palavras para lembrar que até por traz desse mero Deputado "popular", há artimanhas, ideologias. 
o homem deixasse de agir mergulhado em egoísmo. Que ao pensar, no agir psicológico, não pensasse apenas em si, no seu bem - falamos principalmente dos donos do capital/poder. O homem em sua vida deveria apor seu senso de autoconservação (querer o melhor apenas para si) como uma preconização acessória e não primordial/precípua.

Isso, porquanto, na vida humana, "a conservação só figura a título de efeito colateral e secundário, em relação a poderes que, por sua vez, são centrais relativamente à vida, poderes que criam, inventam, fabricam, expandem-se [...] etc." (BACELAR, 2003, p. 37), ou seja, deveria o homem enxergar que a vida é mais do que ser egoísta. A vida é o plexo de relações que empreendemos a todo o momento, nossas conversas nas ruas, nos bares, nas universidades, nossos passeios, nossos divertimentos.

Outrossim, em uma espécie de "contraditório textual", abordamos agora um pensamento oposto ao dito nas linhas anteriores, ou seja, uma perspectiva de defesa do egoísmo humano. Não é nosso pensamento e sim de Ayn Rand (1905-1982), uma filósofa russa que se comportou com uma das maiores teóricas a tratarem o egoísmo em bases psicológicas. Em sua clássica obra "A virtude do egoísmo" (1991), a autora elogia muito o egoísmo enquanto mecanismo/ elemento da mente humana, bem como supervaloriza a autossustentação e o individualismo capitalista. Vamos abordar um pouco de suas ideias para, obviamente, refutá-las e tentarmos pensar um pouco sobre se realmente não há fugas para o egoísmo.

Para a autora, diferentemente do que pensava Karl Marx, Friedrich Engels e tantos outros, a realidade objetiva existe independentemente da consciência do homem, não existe a partir da tomada de consciência da humanidade, bem como não é construída pela mente humana. A partir daí, prega a filósofa que deve cada homem reconhecer-se como um fim em si mesmo e, valorizando seu autointeresse racional, buscar sua felicidade própria, seu próprio benefício.

Rand (1991) prega que o homem possua uma "consciência saudável", nomeação que ela dá para uma mente que apreende os conceitos da realidade e, objetivando controlar tal realidade, age de maneira independente. As ideias da filósofa são a nosso ver frias e conservadoras, mas as apresentamos justamente para rechaçar ainda mais o egoísmo. Diz a filósofa que a razão é um atributo individual, de cada mente humana e, por isso, não existe uma razão coletiva, devendo o homem pensar e ao pensar somente pensar em si próprio. Para ela o Estado deve existir justamente para garantir as liberdades individuais, bem como para garantir que as pessoas sejam protegidas de violências diversas.

A filósofa prega uma valorização do orgulho e um menosprezo pela humildade. Para a pensadora, estas duas características integram a autoestima do homem e, para que esta seja elevada, o quantum de orgulho deve se sobressair em face da humildade. O orgulho, afirma, é a resposta à eficiência na empreitada de o homem buscar seus próprios objetivos exclusivamente, bem 
como a humildade se refere ao fracasso, a não eficiência no auto realizar-se. A filósofa ladeia a dor à humildade e o prazer ao orgulho.

Aduz a autora que "ao permitir que o homem experimente, em sua própria pessoa, o sentido de que a vida é um valor, e que ele é um valor, o prazer serve como combustível emocional da existência do homem" (RAND, 1991, p. 80). De fato, todos pensamos que o prazer não é em todo ruim, mas, cabe perguntar: ao ter prazer (boa casa, comida, roupa etc.), por que privar nosso semelhante de também tê-lo? A pouca quantidade de recursos serve de desculpa mesmo?

Rand (1991) esclarece que as relações humanas não devem ser vividas num lastro de sentimentos que ela chama de "irracionais", como a piedade ou qualquer outra emoção que não entrone o egoísmo. A filósofa diz que os seres humanos vivem cotidianamente tentando manter suas vidas (não morrer), o que fazem pela razão (antecipando consequência de atos etc.). Acredita ela que caso o homem aja com irracionalidade, como os animais, tenderá fortemente à destruição.

Decerto, é um pensamento correto. Basta vermos os animais, um cachorro, por exemplo, atravessa ruas sem se importar com possíveis atropelos por veículos. Usa o intelecto, pensa, mas não tem razão. Porém, cabe perguntar: por que extrapolar este egoísmo físico, biológico, de auto conservação e transformá-lo em uma espécie de "egoísmo social", quase odiando que os outros, os nossos semelhantes, também vençam, também abram suas arcadas dentárias propalando sorrisos etc.? Por que não alimentar o faminto, medicar o doente? Isso tudo dói na alma?

A autora insculpe haver uma deturpação do conceito de egoísmo. Assevera que ser egoísta não é "não pensar no outro" e sim é "apenas pensar em si". Prima ela que no lugar de "não julgue, que não será julgado" deveria o homem ter como base a máxima "julgue e esteja preparado para ser julgado". Correto, mas qual a diferença disso (só pensar em si) em relação a não pensar no outro?

Afirma a pesquisadora:

No uso popular, a palavra "egoísmo" é um sinônimo de maldade; a imagem que invoca é de um brutamontes homicida que pisa sobre pilhas de cadáveres para alcançar seu próprio objetivo, que não se importa com nenhum ser vivo e persegue apenas a recompensa de caprichos inconsequentes do momento imediato. Porém, o significado exato e a definição do dicionário para a palavra "egoísmo" é: preocupação com nossos próprios interesses. Este conceito não inclui avaliação moral; não nos diz que a preocupação com os nossos próprios interesses é boa ou má; nem nos diz o que constitui os interesses reais do homem (RAND, 1991, p. 14). 
A autora está correta. A preocupação com nossos próprios interesses não é ruim, contudo, pensamos que nos preocuparmos apenas com nossos interesses sim é ruim/mau, posto que devemos todos ajudar nossos semelhantes, nos importarmos com eles, afinal é com eles que vivemos, é deles que às vezes precisamos, são eles que nos escutam. Só sou Eu, porque há o outro, a quem me comparo constantemente. Como disse Bakhtin (2012), só sou Eu, pois não me vejo no outro, o reconheço como Outro e vejo que não sou ele, logo, sou Eu. Cremos sim haver uma avaliação moral que precisa ser feita no "agir pensando apenas em si". O homem não está sozinho no mundo. Lutar contra nós mesmos parece "burrice" nossa (do homem). Claro, é utopia, posto que as elites querem mesmo é dinheiro, poder e para isso até matam!

\section{CONSIDERAÇÕES FINAIS}

Finalizando as reflexões e inflexões realizadas nas singelas palavras aqui expendidas, acreditamos que o ideal seria sim cuidarmos de nós mesmos, buscarmos nossas melhoras, nossas vitórias, queremos dinheiro para nós, mas também pensarmos no Outro, no nosso semelhante. Não devemos ter como bonitas apenas atitudes filantrópicas, pois deve sim ser considerada bela uma atitude de autoamor, autocuidado. Mas, por que não conciliar isso com um amor pelo próximo (e pelo distante também)? O egoísmo (físico, biológico) em si não é tão mortal - para nós, o problema está justamente no egoísmo social, esse que praticamos no dia a dia, na vivência, momento em que lutamos uns contra os outros, elevando a misantropia.

O dinheiro não é tudo, nem pode tudo. Há outros significantes sociais que com ele dialogam. Por certo, há antídotos contra a alienação, a paixão, a fissura, a idealização e o simbolismo que o dinheiro e seus artifícios nos trazem à cena da/na vida social. Devemos buscar tais significantes, identificálos, analisá-los. Sabemos ser deveras complexo este tema, porquanto nada é absoluto e às vezes pode o homem se deparar com situações em que tenha de escolher se auto sacrificar ou não pelo seu semelhante, situações bem complexas e que demandam muita avaliação (um filho morrer pelos pais etc., dar dinheiro a um estranho, por exemplo). Mas, fato é que ajudar os outros a terem melhores vidas não é ruim, faz bem, toca em nossas almas, realimenta nossos espíritos - não falamos de filantropia barata e sim de um amor pela humanidade, um sentimento existencial, totalizante. Sejamos mais humildes e amorosos. Reflitamos sobre o egoísmo, sobre nossas relações com o dinheiro. Isso também é Ciência. 


\section{REFERÊNCIAS}

AMARAL, Roniere Ribeiro do. Sobre a sociologia econômica de Max Weber. Revista Soc. estado. vol.17, n. 1, Brasília Jan./June, 2002, p. 206-2012. Disponível em: <http:/ / www.scielo.br/scielo.php?script=sci_arttext\&pid=S0102-69922002000100011 > . Acesso em: 28 maio 2017.

ABREU, Leonardo Lani de. A construção social do Estado de exceção. Rio Branco: IV Encontro Regional Norte de História da Mídia (Universidade Federal do Acre), 2016. (Comunicação Oral).

AGAMBEN, Giorgio. Homo Sacer: o poder soberano e a vida nua. Tradução de Henrique Burigo. Belo Horizonte: Editora da UFMG, 2002.

BACELAR, Kleverton. Psicologia e metafísica em Sobre o fundamento da moral. Revista de Filosofia Aurora, Curitiba, v. 15, n. 16, jan./jun., 2003, p. 25-40. Disponível em: <http:/ / www2.pucpr.br/reol/pb/index.php/rf?dd1=105\&dd99=view\&dd98=pb $>$. Acesso em: 28 maio 2017.

BAKHTIN, Mikhail. Para uma filosofia do ato responsável. Tradução de Valdemir Miotello e Carlos Faraco. 2. ed. São Carlos: Pedro e João, 2012.

BARTH, Maurício. Da necessidade ao desejo: o consumo de luxo e a ascensão do querer. Revista Eletrônica Temática, João Pessoa, ano VI, n. 11, nov., 2010, p. 1-13. Disponível em: <http:/ / www.insite.pro.br/2010/novembro/consumo_desejo_barth.pdf>. Acesso em: 28 maio 2017.

BASTOS, Ronaldo. O conceito do Direito em Marx. Porto Alegre: Fabris, 2012.

BAUMAN, Zygmunt. O amor líquido. Rio de Janeiro: Zahar, 2004.

BOURDIEU, Pierre. O poder simbólico. 4. ed. Rio de Janeiro: Bertrand Brasil, 2001.

CASSIRER, Ernst. A filosofia do iluminismo. Tradução de Álvaro Cabral. Campinas: Editora da Unicamp, 1992.

CHARTIER, Roger. Introdução: Por uma sociologia histórica das práticas culturais. In: CHARTIER, Roger. A história cultural: entre práticas e representações. Lisboa: Editora Difel, 1990, p. 13-28.

CHOMSKY, Noam. Por que tenho esperanças (Entrevista). Tradução de Inês Castilho. Rio de Janeiro: Revista Fórum, 2016, n.p. Disponível em: <http:/ /www.revistaforum. com.br/2016/02/17/chomsky-por-que-tenho-esperancas/>. Acesso em: 28 maio 2017.

DELRUELLE, Edouard. Metamorfoses do sujeito: a ética filosófica de Sócrates a Foucault. Lisboa: Instituto Piaget, 2004.

FLOR, Gisele. Corpo, mídia e status social: reflexões sobre os padrões de beleza.

Revista de Estudos da Comunicação (PUC-PR), Curitiba, v. 10, n. 23, set./dez., 
2009, p. 267-274. Disponível em: <http:/ / www2.pucpr.br/reol/pb/index.php/ comunicacao?dd1=3635\&dd99=view\&dd98=pb>. Acesso em: 28 maio 2017.

FREUD, Sigmund [1908]. Caráter e erotismo anal. Tradução de J. Salomão. Rio de Janeiro: Imago, 1978.

LUZ, Gerson Vasconcelos. O problema do egoísmo humano a partir da concepção hobbesiana de Estado de natureza. Theoria - Revista Eletrônica de Filosofia, Pouso Alegre - MG, v. VI, n. 16, 2014, p. 113-121. Disponível em: <http:/ /www.theoria.com.br/?p=662>. Acesso em: 28 maio 2017.

MARQUES, Francisco Miguel Bracons Felizol. A tragédia da liberdade da Filosofia do Dinheiro de Georg Simmel. Dissertação de Mestrado (Mestrado em Filosofia: Ética e Política). Lisboa: Universidade de Lisboa, 2011, 145p. Disponível em: <http:/ / repositorio.ul.pt/bitstream/10451/4574/1/ulfl101176_tm.pdf >. Acesso em: 28 maio 2017.

MBEMBE, Achille. Crítica da razão negra. Lisboa: Antígona, 2014.

MIRA Y LÓPEZ, Emílio. Manual de psicologia jurídica. Tradução de Ricardo Gama. 2. ed. Campinas: LZN, 2005.

RAND, Ayn. A virtude do egoísmo. Tradução de Winston Ling e Cândido Mendes Prunes. Porto Alegre: Ortiz, 1991.

SACADURA ROCHA, José Manuel de. Michel Foucault e o Direito. Rio de Janeiro: Forense, 2011.

SANTOS, Milton. Dinheiro e território. Geographia - UFF, Rio de Janeiro, n. 1, ano 1, 1999, p. 7-13. Disponível em: <http:/ / www.uff.br/geographia/ojs/index.php/ geographia/article/viewArticle/2>. Acesso em: 28 maio 2017.

SATIE, Luís. Estética e ética em Kant. Revista Filosofia Unisinos, jan.-abr., 2009, p. 2836. Disponível em: <http://revistas.unisinos.br/index.php/filosofia>. Acesso em: 28 maio 2017.

A reflexão estética na filosofia de Kant. Revista Acta Scientiarum, Maringá, v. 32, n. 1, 2012, p. 73-80. Disponível em: <http:/ / periodicos.uem.br/ojs/index.php/ ActaSciHumanSocSci/article/view/7060/706>. Acesso em: 28 maio 2017.

SCHOPENHAUER, A. O mundo como vontade e representação. Rio de Janeiro: Contraponto, 2001.

. Sobre o Fundamento da Moral. Tradução de Maria Lúcia de Mello Cacciola. São Paulo: Martins Fontes, 1995.

SIMMEL, Georg. A filosofia do dinheiro. Tradução de Antonio Carlos Santos. Frankfurt: Suhrkamp, 1989. 
TUGENDHAT, Ernst. Lições sobre ética. Tradução de Ernildo Stein e Ronai Rocha. Petrópolis: Vozes, 1996.

VIEIRA, Érico Douglas; STENGEL, Márcia. Os nós do individualismo e da conjugalidade na pós-modernidade. Revista Aletheia, n. 32, ago., Canoas, 2010, p. 148-160. Disponível em: <http:/ / pepsic.bvsalud.org/pdf/aletheia/n32/n32a12.pdf >. Acesso em: 28 maio 2017. 